\title{
JUURNAL_RU
}

COMPANY GROUP "INTELLEKT"

\author{
Сухарева С.В. \\ ТГУ имени Г.Р.Державина \\ Тамбов, Россия
}

doi: 10.18411/1j2016-3-98

\section{Управление клиентской лояльность в сфере услуг, на примере салона красоты «Оксана»}

Огромный вклад в изучение лояльности принес в науку Фредерик Рейчхельд (президент международной консалтинговой фирмы Baind and Company). Фредерик Р. собрал материал по проведению маркетинговых исследований, проводимых и осуществляемых различными компаниями на предмет установления степени удовлетворенности потребителей[1].

Под лояльностью понимается положительное отношение потребителей в отношении всего, что касается деятельности организации, реализацией услуг, оказываемых организацией, межличностных отношений персонала компании, имиджа организации на рынке услуг, торговых марок, логотипа, и многое другое.

Салонный бизнес как объект продвижения на рынке является очень специфичной структурой, так как относится к сложному типу услуг, потому что в его работе задействовано большое количество специалистов из различных областей, в том числе и из медицинской сферы. В связи с тем, что в настоящее время на рынке салонного бизнеса, как в России, так и в мире наблюдается подъем, а в некоторых странах на лицо избыток салонов красоты, то рынок рекламы в данной области испытывает постоянные изменения.

В данное время в России образуется большое количество ничем не выделяющихся салонов красоты; следствием этого является то, что потребитель 
путается в брендах, в разнообразии ассортимента услуг, и из всех представленных салонов знает лишь несколько. В итоге бюджеты, которые потраченны на рекламу и брендинг, не окупаются в той мере, в какой бы этого хотелось владельцам салонов. Успех салонного бизнеса напрямую зависит от мнения общества. От формирования позитивного имиджа зависит успех работы салона и постоянный приток новых клиентов, что в свою очередь способствует увеличению количества постоянных клиентов салона[3].

Привлечение внимания на современном этапе развития салонного бизнеса к проблемам продвижения бренда салона красоты вызывает несколькими причинами:

Во-первых, эта сфера бизнеса, которая увеличивает темпы роста из года в год.

Во-вторых, по мере увеличения спроса на услуги салонов красоты, возрастает и конкуренция между брендами.

В-третьих, в наши дни многие традиционные инструменты, используемых для создания и продвижения бренда, становятся привычными для потребителей, и из-за этого возникает их малоэффективность.

Очень часто новые салоны стараются скопировать на уже существующие, или предлагая модные услуги, но ни то, ни другое не дает нужного результата и не способствует формированию базы данных клиентов.

Цель исследования состоит в выявлении специфики управления клиентской лояльностью в сфере сервиса, на примере салона красоты «Оксана»

Объект исследования - это клиентская лояльность салона красоты «Оксана».

Предметом исследования является салон красоты «Оксана» г.Тамбова.

В ходе исследования, были выявлены ряд проблем по утечки клиентов из существующей базы. В связи с такими выводами, было принято решение о проведение дополнительные рекламные компании салона красоты «Оксана». В связи с наступлением летнего периода, время отпусков, многие постоянные 
клиенты уезжают на длительные сроки, и здесь необходимо предпринимать дополнительные меры по привлечению потенциальных клиентов:

1.Реклама на такси будет хорошим вариантом рекламы, так как, припарковав его на стоянке, он будет работать ориентиром для будущих клиентов. Кроме этого, при необходимости его можно поставить на другое место или отправить по маршруту в Советском районе г.Тамбова.

2.Салон красоты будет развивать свои странички в таких социальных сетях, как Facebook и Vkontakte. На этих страницах будет размещаться лишь основная информация о данной организации, услугах и акциях. Страница Vkontakte представляет собой открытую группу, куда может вступить любой желающий. В группе представляется ежедневно много интересной и полезной информации на тему здоровья и красоты[3]. Помимо этого там будут публиковаться новости салона, интересные видео, музыка, факты. На страничке в Facebook кроме новостей салона будет размещаться информация о новинках косметологии и средств ухода, которые можно использовать в условиях салона, а так же домашних условиях. Все материалы, которые размещены в группе, проиллюстрированы, потому что это наибольший эффект для привлечения внимания клиента, чем публикация большого текста, который пользователи читать не станут.

3.В один из вечеров можно пригласили клиентов салона на мастер-классы, это поможет завоевать положительное отношение клиентов и запустит волну «сарафанного радио». На мероприятии могут быть продемонстрированы новые услуги, новые тенденции в индустрии красоты. После мероприятия вся информация будет выставлена в социальные сети, а участники отмечены, благодаря этому посещаемость групп в Facebook и Vkontakte, увеличится.

Таким образом, в ходе проведения рекламной компании удалось повысить клиентскую базу салона красоты «Оксана». В дальнейшем, планируется продолжить комплекс маркетинговых мероприятий для развития услуг 
существующим клиентам в будущем, предоставления им дополнительных услуг, продвижения корпоративных идей и ценностей.

\section{Литература:}

1. Котлер Ф., Армстронг Г., Сондерс.Д., Основы маркетинга. - М.: СПб, К.: Вильямс, 2008. - 944c.

2. Официальный сайт Библиофонд [Электронный ресурс]. Режим доступа: http://bibliofond.ru/view.aspx?id=555490/, свободный.- Загл. с экрана.- Яз. pyc.

3. Фролов С. С., Связи с общественностью в работе фирмы. Стратегия, коммуникации, имидж, брендинг. Либроком, 2011. - 368 с. 